\title{
Analisis Terhadap Fungsi Pasar Terpadu Dinoyo Pasca Relokasi Kecamatan Lowokwaru Kota Malang Tahun 2018
}

\author{
Desy Triana Dewi Harizah ${ }^{1, *}$; Triwahyudianto ${ }^{1}$; Dwi Fauzia Putra ${ }^{1}$ \\ ${ }^{1}$ Program Studi Pendidikan Geografi, Universitas Kanjuruhan Malang, Malang 65148, Indonesia \\ Email:*desytrianadw@gmail.com; v.diant@yahoo.com; dwifauziaputra@unikama.ac.id
}

Dikirim : 19 Maret 2019

Diterima: 29 Maret 2019

\begin{abstract}
Abstrak: Pasca relokasi Pasar Terpadu Dinoyo sudah mulai berjalan kembali, akan tetapi masih terdapat keluhan yang di sampaikan oleh pedagang maupun pembeli sendiri mengenai kondisi pasar saat ini. Mengingat sampai sekarang ini masih terdapat kios-kios kosong yang tidak di buka bahkan disewakan dan ada juga yang di jual, sehingga bagian depan pasar tampak kosong. Penelitian ini bertujuan untuk mengetahui: (1) Struktur sosial di Pasar Terpadu Dinoyo. (2) Berjalannya sistem pada struktur sosial di Pasar Terpadu Dinoyo. (3) Fungsi dan disfungsi Pasar Terpadu Dinoyo. Penelitian ini menggunakan pendekatan kualitatif deskriptif. Pengumpulan data yang di gunakan dalam penelitian ini adalah observasi, wawancara dan dokumentasi. Peneliti melakukan wawancara dengan beberapa informan yaitu: pengelola pasar, pedagang, pembeli, mahasiswi, beserta masyarakat sekitar pasar. Teknik analisis data menggunakan wawancara dan dokumntasi kemudian data diolah sesuai dengan fokus penelitian sehingga di temukan temuan data. Hasil penelitian ditemukan bahwa: (1) Struktur yang terdapat di Pasar Terpadu Dinoyo di bagi menjadi dua yaitu di dalam dan di luar pasar. (2) Struktur pasar yang mempunyai pengaruh besar terhadap berfungsinya pasar adalah pengelola pasar. (3) Pasar Terpadu Dinoyo memiliki fungsi dan disfungsi. Fungsi pasar bagi masyarakat sekitar dan mahasiswi adalah mempermudah dalam memenuhi kebutuhannya, sedangkan disfungsinya pasar ini masih terdapat banyak kios-kios kosong terutama di bagian depan pasar. Peneliti selanjutnya dapat meneruskan penelitian ini dengan meneliti lebih lanjut kesimpulan yang dihasilkan dari penelitian ini.
\end{abstract}

Kata kunci: pasar terpadu, relokasi, fungsi dan disfungsi

\section{Pendahuluan}

Berkembangnya zaman modern saat ini banyak ditemukan tempat perbelanjaan modern seperti: minirmarket, supermarket hingga hypermarket yang dapat mengganggu keberadaan pasar tradisional yang jam operasionalnya juga lebih lama daripada pasar tradisional. Karakteristik pasar tradisional dan pasar modern di Indonesia dapat dilihat dari dua aspek, yaitu aspek pelayanan dan aspek fisik (Mukbar, dalam Setyawan,dkk 2015). Dilihat dari segi pelayanan pada pasar tradisional dapat dilakukan tawar menawar antara penjual dan pembeli sehingga harga yang didapatkan relatif murah. Untuk pasar modern sediri pelayanan dilakukan sendiri artinya barang sudah tersedia tidak dapat di tawar dan harganya relatif lebih mahal. Dari segi fisik, kondisi pasar cenderung identik dengan becek, bau, dan kotor serta tatanan yang tidak rapi berbeda dengan pasar modern dimana tempatnya lebih mewah, bersih dan wangi serta tatanan yang rapi sesuai dengan barang dagangan yang dijual sehingga membuat para pembeli betah dan senang berbelanja di pasar modern. Adanya pasar modern dapat mengancam keberadaan pasar tradisional karena masyarakat ekonomi menengah keatas lebih cenderung suka berbelanja di pasar modern.

Pembangunan pasar merupakan salah satu dari perencanaan kota, dimana perencanaan yang berkaitan dengan pengalokasian lahan dalam berbagai macam fungsi dan lahan. (Conyers dan Hill dalam Hariyono 2010) ahli perencanaan kota, menyebutkan bahwa perencanaan merupakan sebuah proses yang berkelanjutan yang menghasilkan keputusankeputusan, atau pilihan-pilihan, tentang alternatif cara penggunaan sumber daya-sumber daya yang memungkinkan, dengan tujuan untuk mencapai suatu bagian dari tujuan dalam jangka waktu tertentu dimasa yang akan datang. 
Sejarah berdirinya Pasar Terpadu Dinoyo ini berawal dari tahun 2012 ketika Pemkot Kota Malang berencana merevitalisasi Pasar Terpadu Dinoyo. Pemerintah Kota Malang merencanakan pembangunan dan pengelolaan Pasar Terpadu Dinoyo dengan sistem Build, Operate, Transfer (BOT) yang bekerjasama dengan investor PT. Citra Gading Asritama. Pembangunan pasar ini menggunakan konsep pasar modern, dimana penataan untuk pengelolaan bangunan di dalam Pasar Terpadu Dinoyo ini akan menggunakan SOP (standard operating procedure) seperti mall. Di dalam pasar terpadu ini terdapat tiga lantai dengan sarana dan prasarana yang baik.

Pada tahun 2017 Pasar Terpadu Dinoyo sudah berjalan, sudah banyak para pedagang yang pindah dan mulai berjualan di Pasar Terpadu Dinoyo. Bagi para pedagang asli Pasar Terpadu Dinoyo pasca reloksi ini tidak membawa dampak. Artinya mereka tetap mempunyai pelanggan, akan tetapi sampai sekarang masih banyak kios-kios kosong yang tidak di buka bahkan disewakan dan ada juga yang di jual, sehingga bagian depan pasar tampak kosong. Hal ini sangat berpengaruh terhadap keramaian pasar. Maka dari itu perlu adanya tindakan yang dilakukan oleh pihak pasar untuk mengatasi permasalahan tersebut. Beberapa para pedagang megatakan bahwasanya ada pedagang yang lebih memilih berdagang di Pasar Landung Sari. Beberapa para pedagang masih merasa lebih nyaman ketika mereka berjualan di pasar merjosari. Alasannya selain sepinya pembeli para pedagang mengeluh mengenai karcis atau iuran yang ditarik oleh pengelola pasar. Selain itu lapak yang diperoleh di Pasar Terpadu ini lebih kecil dan sempit dari pada lapak yang di Pasar Merjosari.

Pada pagi hari pasar beroperasional seperti biasanya, artinya banyak pengunjung yang berbelanja di pasar ini. Akan tetapi, memasuki siang hari pengunjung mulai sepi sehingga aktivitas pasar di siang hari terlihat senggang, dan bahkan ada beberapa para pedagang yang menutup kiosnya hanya sampai siang hari. Sehingga pasar terlihat hanya beroperasi setengah hari saja. Dalam Pasar Terpadu Ini terdapat struktur di antaranya, adanya pengelola, pedagang dan pembeli itu sendiri.

Pada penelitian ini peneliti menggunakan teori struktural fungsional. Dimana setiap struktur di dalamnya saling berfungsi satu sama lain. Oleh karena itu peneliti tertarik untuk mengetahui bagaimanakah berjalannya sistem pada struktur sosial di Pasar Terpadu Dinoyo serta fungsi dan disfungsi Pasar Terpadu Dinoyo. Berdasarkan uraian di atas penelitian ini dilakukan pasca relokasi Pasar Terpadu Dinoyo yang masih menuai pro dan kontra mengenai relokasi ini. Dilihat dari keadaan di lapangan bahwasanya dari segi fisik bangunan sudah memenuhi syarat akan tetapi masih dijumpai banyak kios-kios kosong yang tutup bahkan dijual dan ada beberapa pedagang yang mengeluh terkait sepinya pembeli di Pasar Terpadu Dinoyo tersebut.

Penelitian safwan, dkk (2018) dengan judul "Faktor-Faktor Yang Mempengaruhi Tidak Berfungsinya Pasar Tradisional (Studi Kasus: Pasar Lamgapang Kecamatan Ulee Kareng Kota Banda Aceh)". Penelitian ini menganalisis beberapa faktor yang mempengaruhi tidak berfungsinya pasar Lamgapang diantaranya lokasi pasar tidak strategis, minimnya pedagang tetap, masih ada pedagang kaki lima yang berjualan di pasar lama, aksesibilitas yang sulit dijangkau, sepinya pembeli, dan jalur lalu lintas yang jauh dari keramaian. Data yang digunakan adalah data primer dan sekunder. Pengolahan data mencakup uji validitas, dan reliabilitas, dengan menggunakan bantuan software SPSS versi 22 dan Analisis data ini menggunakan analisis deskriptif.

Penilitian Hidayah (2017) dengan judul Analisis Pelaksanaan Relokasi Pedagang Kaki Lima Di Pasar Simpang Padang Duri Kecamatan Mandau Kabupaten Bengkalis. Pada penelitian ini Pemerintah merelokasi para pedagang kaki lima yang menempati bahu jalan Pasar Simpang Padang Duri tersebut ke Pasar Mandau Raya, Pasar Inpres, dan Pujasera. Dari adanya relokasi ini terdapat faktor penghambat dan pendukung. Peneliti menggunakan 
jenis penelitian deskriptif kualitatif. Pada penggumpulan data peneliti menggunakan wawancara, dokumentasi dan observasi. Kemudian peneliti melakukan analisis data dengan menggunakan tiga komponen pokok tersebut adalah reduksi data, penyajian data dan penarikan kesimpulan

\section{Metode Penelitian}

Penelitian ini menggunakan pendekatan kualitatif dengan jenis penelitian secara deskriptif dan metode studi kasus. Jenis penelitian ini adalah deskriptif dimana pada penelitian mengarah pada pengungkapan suatu masalah atau keadaan sebagaimana adanya dan mengungkapkan fakta-fakta yang ada, walaupun kadang-kadang diberikan interpretasi atau analisis. Penelitian ini menggunakan strategi studi kasus karena merupakan salah satu jenis penelitian yang dapat menjawab beberapa issue atau objek akan suatu fenomena terutama di dalam cabang ilmu sosial. Teknik pengumpulan data pada penelitian ini peneliti menggunakan metode observasi, wawancara dan dokumentasi. Dimana pada penelitian ini terdapat 23 informan yang terdiri dari: 2 pengelola pasar, 5 pedagang pasar, 4 pembeli di pasar, 5 mahasiswi UNISMA, 4 masyarakat sekitar pasar dan 3 pedagang yang berjualan di sekitar pasar.

\section{Pengumpulan data}

Untuk memperoleh data-data yang diperlukan oleh peneliti maka diperlukan beberapa metode untuk pengumpulan data. Sehinga data-data diperoleh secara akurat. Metode yang digunakan sebagai berikut:

Observasi

Morris, dalam Hasyim Hasanah, 2016:26 mendefinisikan observasi sebagai aktivitas mencatat suatu gejala dengan bantuan instrumen-instrumen dan merekamnya dengan tujuan ilmiah atau tujuan lain. Menurut Marshall, dalam Sugiyono 2017:106 menyatakan melalui observasi, peneliti belajar tentang perilaku, dan makna dari perilaku tersebut. Jadi observasi merupakan sebuah pengamatan studi kasus yang dilakukan dengan sengaja, terarah, urut dan sesuai dengan hasil tujuan. Pada penelitiaan ini teknik observasi yang di lakukan secara terang-terangan. Observasi ini dilakukan untuk mendapatkan data dari sumber berupa, peristiwa, tempat atau lokasi, benda dan rekaman gambar. Dalam penelitian ini peneliti melakukan observasi yang bersifat langsung (partiscipatif observation), karena peneliti terlibat lansung dalam percakapan wawancara dengan pedagang di Pasar Terpadu Dinoyo, menyimak, dan mencatat temuan dilapangan.

Wawancara

Menurut Eisterberg, dalam Sugiyono 2017:114 Wawancara adalah merupakan pertemuan dua orang untuk bertukar informasi dan ide melalui tanya jawab, sehingga dapat dikonstruksikan makna dalam suatu topik tertentu. (Wawancara yang digunakan dalam penelitian ini termasuk dalam jenis wawancara semi berstruktur dan open-ended, karena dalam wawancara ini peneliti menggunakan pertanyaan-pertanyaan terstruktur tetapi juga bersifat bebas dan terbuka sehingga informan dengan sukarela memberikan keteranganketerangan sesuai dengan masalah yang diteliti. Dalam wawancara peneliti juga dapat menggunakan perekam suara.

\section{Dokumentasi}

Dokumentasi merupakan salah satu jenis metode yang sering digunakan dalam metodologi penelitian sosial, dimana dokumentasi ini sebagai bukti akurat ketika di lapangan. Menurut Sugiyono 2005:83 studi dokumen merupakan pelengkap dari penggunaan metode observasi 
dan wawancara dalam penelitian kualitatitif maupun kuantitatif. Dalam penelitian ini dokumen yang digunakan adalah foto-foto pendukung pernyataan subyek, laporan-laporan suatu peristiwa, serta surat-surat yang diperlukan selama proses penelitian.

\section{Analisis data}

Dalam penelitian ini peneliti mengunakan metode analisis data modell Miles dan Huberman. Analisis data dalam kualitatif dilakukan secara interaktif dan berlangsung secara terus menerus sampai datanya jenuh (Huberman, dalam Sugiyono 2017:133). Aktivitas dalam analisis data, yaitu data reduction, data display dan conclusion drawing atau veryfication.

Data Reduction (Reduksi Data)

Data yang diperoleh dari lapangan cukup banyak, untuk itu perlu dilakukan analisis data melalui reduksi data. Mereduksi data berarti merangkum, memilih data yang didapat sesuai dengan fokus penelitian. Dengan demikian data yang telah direduksi akan sesuai dan memberikan gambaran kepada peneliti, dan mempermudah peneliti untuk melakukan pengumpulan data selanjutnya, dan mencarinya bila diperlukan. Reduksi data dapat dibantu dengan peralatan elektronik seperti laptop, dengan memberikan kode pada aspek-aspek tertentu (Sugiyono, 2017).

Data Display (Penyajian Data)

Setelah data di reduksi sesuai dengan apa yang di butuhkan, maka langkah selanjutnya adalah mendisplaykan data. Pada penelitian kualitatif, penyajian data bisa dilakukan dalam bentuk uraian singkat disertakan dengan narasi hasil wawancara, bagan, hubungan antar kategori, flowchart dan sejenisnya. Dalam hal ini (Miles dan Huberman, dalam Sugiyono, 2017:137) yang digunakan peneliti untuk menyajikan data dalam penelitian kualitatif adalah dengan teks yang bersifat naratif. Dengan begitu akan memudahkan peneliti untuk memahami apa yang terjadi, merencanakan kerja selanjutnya berdasarkan apa yang difahami tersebut (Milers dan Huberman dalam Sugiyono, 2017:138)

Conclusing Drawing (Verification)

Langkah terakhir dalam analisis data kualitatif menurut Miles and Huberman adalah penarikan kesimpulan dan verifikasi. Kesimpulan awal yang masih dikemukakan masih bersifat sementara, dan akan berubah bila tidak ditemukan bukti-bukti yang kuat yang mendukung pada tahap pengumpulan berikutnya.

\section{Hasil dan Pembahasan}

\section{Struktur sosial pasar terpadu dinoyo}

\section{Aktivitas di dalam pasar}

Struktur sosial yang terdapat di Pasar Terpadu Dinoyo ini di bagi menjadi dua yaitu di dalam dan luar pasar. Sistem sosial yang berlangsung di dalam Pasar Terpadu Dinoyo ini dapat dilihat dengan adanya interaksi antara individu dengan individu, kelompok dengan kelompok, atau antara instansi dengan instansi. Hal ini dijelaskan oleh informan pada saat melakukan wawancara yaitu:

"Ya aktivitasnya ada jual beli yang pasti. Ada aktivitas tawar menawar, dan ada interaksi juga. Ada koperasi juga, terus pasar ini kan mau berstandart SNI, ya standart SNI itu ada poli, koperasi, paguyuban, ada klinik konsultasi untuk pedagang”. (Zaini, 30 November 2018). 
Selain transaksi jual beli Pasar Terpadu Dinoyo ini biasanya sering mendapat kunjungan dari dinas-dinas terkait untuk memantau situasi dan kondisi pasar. Hal ini di jelaskan oleh informan yaitu:

"Kalau yang di pasar yang jelas ada transaksi jual beli, terus kemudian ada juga dari dinas. Dalam hal ini Bulog yang dimana setiap pasar pasti ada yang namanya Bulog untuk melakukan operasi pasar. Terus ada juga dari dinas-dinas yang terkait dalam hal ini contoh seperti dinas kebersihan untuk pengangkutan sampah. Kalau untuk pedagang seperti biasa saya ulangi sekali lagi di transaksi jual beli”. (Yosi, 4 Desember 2018)

Serta ada beberapa kegiatan sosial rutin seperti pengajian dan arisan antar pedagang. Hal ini dilakukan untuk membangun komunikasi yang baik biasanya antar pedagang sering mengadakan kegiatan sosial yang rutin dilaksanakan. Hal ini di jelaskan oleh informan yaitu:

"Ya jelas jual beli, tapi ya terus dari segi sosialnya ya ada, terus kadang ada pengajian, terus biasanya juga ada persatuan arisan untuk pedagang, semua untuk pedagang. Kalau yang beraktivitas lainnya ya pada dasarnya jual beli ya karena ini kan emang pasar ya gitu mbak”. (Hasan, 30 November 2018).

Menurut Marzali (2006) tujuan dari kajian-kajian struktural-fungsionalisme adalah untuk membangun suatu sistem sosial, ataupun struktur sosial, melalui pengkajian terhadap pola hubungan yang berfungsi antara individu dengan individu, antara kelompok dengan kelompok, atau antara institusi dengan institusi sosial di dalam suatu masyarakat, pada suatu kurun masa tertentu

\section{Aktivitas di luar pasar}

Pasar Terpadu Dinoyo ini juga berdekatan dengan permukiman warga dan di samping pasar sendiri terdapat Mall, serta lokasi pasar yang berdekatan dengan Kampus yang memungkinkan juga adanya lalu lalang mahasiswa mengingat lokasi pasar yang sangat dekat dengan area kampus, Serta terdapat banyak warung makan atau toko-toko yang berada di sekitar pasar itu sendiri. Hal ini di jelaskan oleh informan yaitu:

"Apa ya...ya disini ini cuman ada kampus, mall, sama ini mbak rumah-rumah warga yang kebanyakan juga setiap rumahnya itu punyak usaha kaya warung-warung gitu” (Ratna, 2 Desember 2018)

Selain itu Aktivitas di luar pasar sendiri ada tukang parkir dimana tukang parkir ini sangat di butuhkan untuk menjaga keamanan kendaraan para pengunjung. Hal ini di jelaskan oleh informan yaitu:

"Ketika gak ada tukang parkir, keamanan kendaraan yo opo? Dari segi parkir. (May, 30 November 2018)”

Secara teoritis hal tersebut sesuai dengan pendapat Durkheim dalam Anto (2018) dimana masyarakat adalah sebuah kesatuan dimana di dalamnya terdapat bagian-bagian yang dibedakan, tetapi dengan adanya perbedaan itu masyarakat dapat saling melengkapi satu sama 
lain dalam kehidupannya. Bagian-bagian dari sistem tersebut mempunyai fungsi masingmasing yang saling berkaitan dan membuat sistem menjadi seimbang.

\section{Berjalannya sistem pada struktur sosial di pasar terpadu dinoyo}

\section{Keterkaitan antar struktur}

Setiap struktur memiliki fungsi tertentu, karena setiap struktur dalam sistem sosial, juga berlaku fungsional terhadap lainnya. Apabila terjadi perubahan pada satu bagian maka akan menyebabkan ketidak seimbangan dan juga dapat menyebabkan perubahan atau fungsi lainnya. Pada Pasar Terpadu Dinoyo setiap struktur juga memiliki fungsi dan peran masingmasing yang saling keterkaitan satu sama lain. Adanya struktur pasar seperti pengelola, pedagang, dan pembeli sendiri sangat penting. Semua struktur tersebut harus ada dan saling terikat. Hal ini di jelaskan oleh informan yaitu:

"Pedagang dengan Pengelola? Jadi gini karena kita satu keterkaitan ya mbak, pedagang juga butuh pengelola dan pengelola juga butuh pedagang. Intinya kami mengusahan disini bagaimana bisa satu keterkaitan, saling kerja sama, saling interaksi dan juga saling menguntungkan, jangan sampai ada salah satu yang di rugikan seperti itu”. ( Yosi, 4 Desember 2018)

Teori struktural fungsional mengakui adanya keberagaman di dalam kehidupan masyarakat dimana dengan keberagaman ini dapat menentukan keberagaman fungsi sesuai dengan posisi seseorang dalam sebuah struktur yang ada di masyarakat. Struktural fungsional pada prinsipnya berkisar pada beberapa konsep, namun yang paling penting adalah konsep fungsi dan konsep struktur. Perkataan fungsi digunakan dalam berbagai bidang kehidupan manusia, yang menunjukkan kepada aktivitas dan dinamika manusia dalam mencapai tujuan hidupnya.

\section{Peranan pengelola pasar}

Struktur Pasar Terpadu Dinoyo ini yang mempunyai pengaruh besar terhadap berfungsinya pasar adalah pengelola pasar. Dimana pengelola pasar mempunyai peranan penting dalam istilah meramaikan pasar. Akan tetapi peranan pengelola pasar disini belum berjalan $100 \%$. Mengingat masih banyak terdapat kios-kios kosong terutama dibagian depan pasar, dan masih terdapat beberapa keluhan dari para pedagang mengenai sepinya pasar. Hal ini juga disebabkan dari dampak masih banyaknya kios-kios kosong. Hal ini di jelaskan oleh informan yaitu:

"Sudah berjalan sih, tapi belum semua karena apa itukan masih ada banyak kios-kios yang kosong. Itukan juga masuk dari bagian tugas pengelola. Jadi kalau di bilang $100 \%$ sih belum cuman sedikit banyak sudah mulai berjalan”. (Hari Jaya, 30 November 2018)

Peranan pengelola pasar sendiri yaitu mengatur dan menata zona pedagang sesuai dengan komoditasnya, menjaga pasar agar tetap kondusif dan berjalan sebagaimana mestinya, memberikan rasa aman, nyaman, dan bersih terhadap pengunjung maupun pedagang sendiri serta diharapkan dapat memberi solusi dan tanggung jawab ketika ada permasalahan di pasar. Hal ini di jelaskan oleh informan yaitu: 
"Peran pengelola ya? Satu disini kita menjaga agar pasar ini bisa kondusif di rasa nyaman, aman, bersih, indah. Kalau disingkat namanya BERIMAN mbak. Baik kepada pedagang maupun kepada pengunjung. Jadi kalau di bilang seberapa penting pengelola dan pedagang sama, sebenarnya sama-sama saling mendukung. Kalau saya bilang seperti itu”. (Yosi,4 Desember 2018)

Menurut Sulistyo dan Cahyono (2010) pasar adalah salah satu fasilitas kota yang berupa wadah untukmenampung orang (penjual, pembeli dan pengelola) dimana barang dagangannya sebagian besar merupakan kebutuhan sehari-hari. Oleh karena itu, dalam aktivitasnya diperlukan adanya fasilitas-fasilias penunjang yang mampu mendukung ke berlangsungan aktivitas perdagangan pasar, yang hal ini merupakan pertimbangan agar wadah tersebut dapat dipergunakan senyaman mungkin bagi pemakainya. Fungsi pasar adalah sebagai mata rantai yang mempertemukan penjual (yang mempunyai barang dan menginginkan uang) dengan pembeli (yang mempunyai uang danmenginginkan barang).

Secara teoritis Ritzer dan Doglas (2004) mengemukakan pendapatnya dimana teori struktural fungsional menjelaskan bagaimana berfungsinya suatu struktur. Setiap struktur akan tetap ada sepanjang ia memiliki fungsi. Asumsi dasar dari teori fungsionalisme struktural adalah setiap struktur dalam sistem sosial juga berlaku fungsional terhadap yang lainnya. Sebaliknya kalau tidak fungsional maka struktur itu tidak akan ada atau hilang dengan sendirinya secara perlahan.

\section{Fungsi dan disfungsi pasar terpadu dinoyo}

\section{Kelebihan pasar terpadu dinoyo}

Fungsi pasar itu sendiri sangat penting bagi masyarakat, mahasiswa dan pedagang di luar pasar. Karena dengan adanya Pasar Terpadu Dinoyo bisa mempermudah masyarakat dan mahasiswa untuk memenuhi kebutuhannya. Masyarakat sekitar merasa terbantu dengan adanya pasar, karena tidak perlu jauh-jauh ketika berbelanja. Hal yang serupa juga dirasakan oleh pedagang sekitar atau luar pasar. Mereka mengakui bahwasanya adanya pasar tidak berpengaruh kepada usahanya walaupun lokasinya berdekatan. Serta lokasi pasar yang strategis juga memudahkan mahasiswa dan masyarakat sekitar yang tidak memiliki kendaraan sehingga bisa jalan kaki dan tidak mengeluarkan ongkos transportasi dan juga mengingat harga di Pasar Terpadu Dinoyo ini masih tergolong murah dapat membantu mahasiswi untuk hemat. Hal ini di jelaskan oleh informan yaitu:

"Mahasiswa itu lebih gampang untuk mencari kebutuhannya, jadi tidak usah jauh-jauh. Seperti kayak saya yang gak punyak kendaraan ini jadi lebih mudah gitu aksesnya". (Zahra, 13 November 2018).

\section{Kelemahan pasar terpadu dinoyo}

Disfungsi pasar masih terdapat kios-kios kosong terutama di bagian depan pasar sehingga merugikan para pedagang maupun pengelola pasar itu sendiri. Hal ini di jelaskan oleh informan yaitu:

"Kelemahannya kalau saya rasa gak terlalu signifikan ya karena masih sepi, mungkin karena kendalanya perpindahan pasar ke sini orang masih mengingat pasar yang dulu masih sepi. 
Intinya gitu. Termasuk juga pengaruh kios-kios kosong-kosong tadi itu, sehingga orang berpikir pasar ini kok sepi”. ( Yosi, 4 Desember 2018)

Pendapat Christaller dalam Ariyani (2015) mengemukakan bahwa tujuan utama sebuah pusat permukiman atau pasar adalah menyediakan barang dan jasa untuk populasi di lingkungan sekitarnya. Sedangkan teori lokasi sesuai dengan pendapat Tarigan dalam Putra (2011) mengemukakan bahwa teori lokasi adalah ilmu yang mempelajari tata ruang kegiatan ekonomi, atau ilmu yang mempelajari tentang alokasi geografis dari sumber-sumber yang potensial, serta hubungannya atau pengaruhnya terhadap berbagai macam usaha atau kegiatan baik ekonomi maupun sosial.

Penelitian Safwan, dkk (2018) yang berjudul faktor-faktor yang mempengaruhi tidak berfungsinya pasar tradisional (Studi kasus: Pasar Lamgapang Kecamatan Ulee Kareng Kota Banda Aceh) dimana terdapat beberapa faktor yang tidak mempengaruhi tidak berfungsinya pasar diantaranya, lokasi pasar yang tidak strategis, minimnya pedagang tetap, masih ada pedagang kaki lima yang berjualan di pasar lama, akssebilitas yang sulit di jangkau, sepinya pembeli, dan jalur lalu lintas yang jauh dari keramaian.

Penelitian selanjutnya oleh Hermanto (2008) yang berjudul faktor-faktor yang berpengaruh paling kuat terhadap fungsi ruang di serambi Pasar Induk Wonosobo, Dimana pedagang yang ada di lantai II dan III Pasar Induk Wonosobo mengeluhkan sepinya pembeli serta kurang meratanya pembeli yang datang di Pasar Induk Lantai II dan III. Perubahan fungsi ruang pada Pasar Induk dengan dipenuhi oleh los-los, merembet ke ruang publik (terminal angkot) yang berada disamping Pasar Induk Wonosobo. Faktor pengaruh yang paling kuat terhadap perubahan fungsi ruang di Serambi Pasar Induk Wonosobo adalah, faktor Penyebaran Jumlah Pembeli. hal tersebut dikarenakan berkaitan dengan sepinya los yang ada di dalam pasar lantai II dan III, sehingga timbul kenginan untuk membangun los-los pasar ruang publik yang notebene dekat dengan pencapaian, serta adanya dukungan dari DPP dalam perijinan

\section{Kesimpulan}

Struktur yang terdapat di Pasar Terpadu Dinoyo di bagi menjadi dua yaitu di dalam dan luar pasar. Hal ini bisa dilihat dari aktivitas yang ada di dalam dan di luar pasar. Untuk struktur pasar sendiri terdiri dari Kepala Pasar, Kabid Kebersihan dan Keamanan, Kabid Retribusi dan Humas, serta Kabid Administrasi. Dimana Kabid Kebersihan, Ketertiban dan Keamanan memiliki bawahan Scurity dan Cleaning Servis, serta Kabid Retribusi dan Humas memiliki bawahan 3 Juru Tarik. Struktur Pasar Terpadu Dinoyo ini yang mempunyai pengaruh besar terhadap berfungsinya pasar adalah pengelola pasar. Dimana pengelola pasar mempunyai peranan penting dalam istilah meramaikan pasar. Akan tetapi peranan pengelola pasar disini belum berjalan $100 \%$. Mengingat masih banyak terdapat kios-kios kosong terutama dibagian depan pasar, dan masih terdapat beberapa keluhan dari para pedagang mengenai sepinya pasar. Fungsi Pasar Terpadu Dinoyo Masyarakat dan pedagang sekitar merasa lebih gampang dan mudah untuk memenuhi kebutuhannya mengingat lokasi pasar yang sangat dekat. Begitu juga dengan mahasiswi mengingat lokasinya yang sangat strategis mempermudah mahasiswi untuk mememnuhi kebutuhan hidupnya dan juga mempermudah bagi mereka yang tidak memiliki kendaraan karena dapat di jangkau dengan jalan kaki, serta dengan adanya Pasar Terpadu Dinoyo ini dapat membantu mahasiswi untuk berhemat. Sedangkan disfungsi pasar masih terdapat banyak kios-kios kosong terutama di bagian depan pasar. Bagi peneliti selanjutnya diharapkan untuk mengkaji lebih banyak lagi sumber maupun refrensi yang terkait dengan penelitian ini. Peneliti juga diharapkan lebih mempersiapkan diri dalam proses pengumpulan data dan segala sesuatunya sehingga hasil penelitiannya dapat lebih baik dan 
lebih lengkap lagi. Pengambilan data dilakukan secara bertahap dan lebih mendalam sehinga data yang diperoleh lebih valid. Serta wawancara yang dilakukan dilapangan mengikuti saran dan arahan yang diberikan oleh tempat penelitian.

\section{Ucapan Terimakasih}

Peneliti menyelesaikan artikel ini tidak terlepas dari bantuan banyak pihak. Oleh karena itu peneliti menyampaikan terimakasih kepada: Universitas Kanjuruhan Malang, Pasar Terpadu Dinoyo sebagai tempat penelitian, Pengelola, Pedagang dan Pembeli di Pasar Terpadu Dinoyo serta Masyarakat sekitar Pasar Terpadu Dinoyo yang telah meluangkan waktunya dan memberikan data-data yang di perlukan oleh peneliti.

\section{Daftar Rujukan}

Ariyani, Bella. 2015. Implikasi Central Place Theory Dalam Jurnal Pola Distribusi Spasial Minimarket Di Kota-kota Kecil. 1-11, (Online), (Https://Www.Academia.Edu/11535688/Implikasi_Central_Place_Theory_Dalam_J urnal_Pola_Distribusi_Minimarket_Di_Kota Kota_Kecil), diakses pada tanggal 28 Oktober 2018

Anto, Rusdi. 2017. Teori-teori Sosiologi Hukum Fungsional: 1-15, (Online), (https://www.researchgate.net/publication/326610706_Teori-

teori_Sosiologi_hukum_Fungsional_Struktural), diakses pada tanggal 25 September 2018

Hariyono, Paulus. 2010. Perencanaan Pembangunan Kota dan Perubahan Paradigma. Yogyakarta: Pustaka Pelajar

Hasanah, Hasyim. 2016. Teknik-Teknik Observasi (Sebuah Alternatif Metode Pengumpulan Data Kualitatif Ilmu -ilmu Sosial). Jurnal Peningkatan Mutu Keilmuan dan Kependidikan Islam. $\quad 8(01)$ : 21-46, (http://journal.walisongo.ac.id/index.php/attaqaddum/article/view/1163) diakses pada tanggal 17 September 2018

Hermanto, Heri. 2008. Faktor-Faktor Yang Berpengaruh Terhadap Perubahan Fungsi Ruang Di Serambi Pasar Induk Wonosobo.Tesis: i-xxi, (Online), (https://core.ac.uk/download/pdf/11717288.pdf) diakses pada tanggal 17 September 2018

Hidayah, Ulfiani Ayu. 2017. Analisis Pelaksanaan Relokasi Pedagang Kaki Lima Di Pasar Simpang Padang Duri Kecamatan Mandau Kabupaten Bengkalis JOM FISIP.4(1):1-10,(Online),

(http://jom.unri.ac.id/index.php/JOMFSIP/article/view/13862) diakses pada tanggal 17 September 2018

Marzali, Amri. 2006. Struktural-Fungsionalisme. Antropologi Indonesia. 30(2): 127137,(Online), (https://www.academia.edu/6568332/StrukturalFungsionalisme_1), diakses pada tanggal 10 September 2018

Putra, Dwi Fauzia. 2011. Relokasi Kios dan Pedagang Kaki Lima Di Belakang Kampus UNS Surakarta. Skripsi: 1-80, (di terbitkan)

Ritzer, George. 2004. Edisi terbaru Teori Sosiologi, yogyakarta: Kreasi wacana

Ritzer, George dan Doglas Goodman J. 2004. Teori Sosiologis Modern, terj. Alimadan. Jakarta: Prenada 
Safwan, dkk. 2018. Faktor-Faktor Yang Mempengaruhi Tidak Berfungsinya Pasar Tradisional (Studi Kasus: Pasar Lamgapang Kecamatan Ulee Kareng Kota Banda Aceh). Jurnal Arsip Rekayasa Sipil dan Perencanaan 1(1): 112-121, (Online), (http://www.jurnal.unsyiah.ac.id/JARSP/article/download/10361/8259), diakses pada tanggal 21 Mei 2018

Setyawan, Samudro, Pratama Yogi Pasca. 2015. Analisis Kebijakan Pemerintah Kota Surakarta Mengenai Pasar Tradisional Dan Pasar Modern. JIEP. 15 (1): 77-85, (Online), (https://jurnal.uns.ac.id/jiep/article/view/9896), diakses pada tanggal 27 Juni 2018

Sulistyo, Heru dan Cahyono Budhi. 2010. Model Pengembangan Pasar Tradisional Menuju Pasar Sehat Di Kota Semarang. EKOBIS. 11 (2): 516 - 526, (Online), http://jurnal.unissula.ac.id/index.php/ekobis/article/viewFile/513/422, diakses pada tanggal 10 September 2018

Sugiyono. 2017. Metode Penelitian Kualitatif. Bandung: Alfabeta 